\title{
Specifics of Building Envelope Air Leakage Problems and Airtightness Measurements
}

\author{
Anatolijs Borodinecs ${ }^{1, *}$, Jekaterina Nazarova ${ }^{1}$, Aleksandrs Zajacs ${ }^{1}$, Alexandr Malyshev ${ }^{2}$ \\ and Vladimir Pronin ${ }^{2}$ \\ ${ }^{1}$ Riga Technical University, LV - 1658 Kalku str. 1, Riga, Latvia \\ ${ }^{2}$ ITMO University, 197101 Kronverksky Ave. 49, St.Petersburg, Russia
}

\begin{abstract}
In addition to transmission heat loses the infiltration of outdoor air can cause significant heat losses. The external building envelope should be airtight in order to prevent uncontrolled cold air infiltration. The article analysis modern building materials and structures influence on airtightness. The practical measurements of renovated buildings' airtightness are presented and compared to non-renovated buildings. In addition paper presents data on airtightness measurements of whole multi apartment building and single apartment in analyzed building taking inco accout properties of building materials. The airtightness of single apartment was evaluated with support pressure in neighbor apartments. The results show that the airtightness measurements of multi apartment building can be evaluated by measuring single apartment on last floor with support pressure in neighbor apartments. The practical measurement of renovated buildings had shown the air leakage rate q50 of typical Latvian construction after renovation is between 2.5 and $2.9 \mathrm{~m}^{3} /\left(\mathrm{m}^{2} \cdot \mathrm{h}\right)$. Since the building envelope has to minimize the heat loses (transmission and infiltration) and ventilation system either mechanical or natural has to provide necessary air exchange, the building envelope airtightness shouldn't be dependent on type of ventilation systems.
\end{abstract}

\section{Introduction}

General, building energy consumption depends on transmission heat losses, infiltration heat losses and ventilation heat losses. While the U-value of building envelope has reached reasonable minimums the requirements for air permeability of building envelop are still under constant review across the EU. The strong requirements for air permeability reduce amount of infiltrated outdoor air, thus minimizing the heat losses. However in some cases the air infiltration is considered as part of natural ventilation. Nowadays Belgium, Germany and some other countries has different air-tightness requirements for building with natural and mechanical ventilation [1]. For example in Germany air permeability of building mechanical ventilation is $1.5\left(\mathrm{~h}^{-1}\right)$ and $3\left(\mathrm{~h}^{-1}\right)$ for building with natural ventilation. It should be noted that natural ventilation as well as mechanical ventilation should ensure necessary air exchange rate independently to outdoor air conditions such as wind and temperature

*Corresponding author: anatolijs.borodinecs@rtu.lv 
difference. Modern energy efficient ventilation systems also have to provide possibilities airflow regulation according to room occupancy [2-6]. The air flow through the buildings envelope couldn't be controlled and additional heat consumption for infiltrated air will be needed even in case of human absence in room. This issue is especially actual in office building, schools and kindergartens, where during the night and weekends the ventilation should ensure only minimal air exchange.

Air tightness of building envelope can be expressed as air permeability q50 $\mathrm{m}^{3} /\left(\mathrm{m}^{2} \cdot \mathrm{h}\right)$ as well as air change rate coefficient $\mathrm{n} 50\left(\mathrm{~h}^{-1}\right)$. The air permeability value q50 directly characterizes properties of building envelope. The air change rate coefficient $\mathrm{n} 50\left(\mathrm{~h}^{-1}\right)$ should be evaluated with the respect to building surface area to volume ratio.

\section{Evaluation of building envelope air leakage}

It is clear that building envelope of modern buildings should be well insulated as well as airtight. The airtight building has both - positive and negative properties. The positive impact of air tightness is possibility to create controlled air supply scheme and to reduce energy consumption for supply air heating [7-11]. This positive effect could be reinforced by use of the ventilation systems with heat recovery. The negative property is lack of natural air supply and additional costs for equipment and exploitation of mechanical ventilation. The negative property of non-airtight buildings is uncontrolled cold air infiltration which requires also additional heat in time than room is not occupied. Existing researches $[12,13,14]$ have proved positive effect of renovation works done in kindergartens and schools. However measurements done in Latvia $[15,16,17]$ have shown significant increase of indoor air $\mathrm{CO}_{2}$ concentration after renovation, which has negative impact on human health.

Almost in all cases the level of building envelope airtightness could not be calculated during design stage. The level of airtightness much more depends on quality of buildings construction works. Especially quality of window/wall joints, quality of brick or block walls and roof/wall joins. The junction solution of prefabricates elements should be carefully evaluated during the design stage. There is no common developed evaluation methodology for building envelope airtightness building at design stage. At the moment there is a strict gradation for windows air leakage [18]. But for external elements such as walls and roofs structures, theoretical evaluation of air leakage is problematic due to the lack of information on building materials air permeability. The study presents data only for limited number of materials [19, 20].

Typically dwelling buildings up to 16 floors are built from concrete panel with mineral wool insulation and with concrete external finishing. The resistance to infiltration through wall's materials itself can be calculated on the data [20] basis:

$$
R_{\mathrm{inf}}=R_{\mathrm{inf}}^{\text {concrete }}+R_{\mathrm{inf}}^{\text {insulation }}+R_{\mathrm{inf}}^{\text {ext. fin }},\left[m^{2} \mathrm{hPa} / \mathrm{kg}\right]
$$

where: $R_{\mathrm{inf}}^{\text {concrete }} ; R_{\mathrm{inf}}^{\text {insulation }} ; R_{\mathrm{inf}}^{\text {ext. fin }}-$ resistance to infiltration of concrete panel, insulation and external finishing, $\left[\mathrm{m}^{2} \mathrm{hPa} / \mathrm{kg}\right]$.

The resistance to infiltration of a wall: $R_{\mathrm{inf}}=39242 .\left[\mathrm{m}^{2} \mathrm{hPa} / \mathrm{kg}\right]$.

Such high resistance to infiltration does not have any impact on total building's energy performance and quality of indoor air.

The air tightness of windows still should be taken into account. The windows with resistance to air leakage $R_{\text {inf }}=0,65 \mathrm{~kg} /\left(\mathrm{m}^{2} \cdot \mathrm{h}\right)$ or $0,3 \mathrm{~m}^{3} / \mathrm{hm}^{2}$ are typically used for dwelling building construction.

The level of infiltrated air through the windows can be calculated [21]: 


$$
G_{0}=\frac{1}{R_{\text {inf }}}\left(\frac{\Delta p}{\Delta p_{o}}\right)^{\frac{2}{3}},\left[\mathrm{~kg} /\left(m^{2} h\right)\right]
$$

For the first floor the level of infiltrated air will be: $G_{0}=\frac{1}{0.65}\left(\frac{23}{10}\right)^{\frac{2}{3}}=2.68,\left[\mathrm{~kg} /\left(\mathrm{m}^{2} \mathrm{~h}\right)\right]$

For the 9th floor: $G_{0}=\frac{1}{0.65}\left(\frac{1}{10}\right)^{\frac{2}{3}}=0.33,\left[\mathrm{~kg} /\left(\mathrm{m}^{2} \mathrm{~h}\right)\right]$

The Comparison of air tightness requirements in different European countries are shown in Table 1 [22].

Table 1. Comparison of air tightness requirements in different EU countries.

\begin{tabular}{|c|c|c|}
\hline \multirow{2}{*}{ EU Member State } & \multicolumn{2}{|c|}{ Air tightness requirements at $50 \mathrm{~Pa}$ pressure } \\
\hline & Natural ventilation & Mechanical ventilation \\
\hline Czech Republic & $4.5[1 / \mathrm{h}]$ & $\begin{array}{l}\text { w/o heat recovery: } 1.5[1 / \mathrm{h}] \\
\text { with heat recovery: } 1.0[1 / \mathrm{h}]\end{array}$ \\
\hline Germany & $\begin{array}{c}3.0[1 / \mathrm{h}] \\
\text { or } \\
7.8 \mathrm{~m}^{3} / \mathrm{h} \text { per } \mathrm{m}^{2} \text { floor area }\end{array}$ & $\begin{array}{c}1.51 / \mathrm{h} \\
\text { or } \\
\text { Germany } 3.9 \mathrm{~m}^{3} / \mathrm{h} \text { per } \mathrm{m}^{2} \text { floor area }\end{array}$ \\
\hline Denmark & \multicolumn{2}{|c|}{$1.5\left[1 / \mathrm{s}\right.$ per $\mathrm{m}^{2}$ floor area $]$} \\
\hline Norway & \multicolumn{2}{|c|}{$3.0[1 / \mathrm{h}]$} \\
\hline The Netherlands & \multicolumn{2}{|c|}{$\begin{array}{c}\left.\text { Dwellings: } 200 \mathrm{dm}^{3} / \mathrm{s} \text { (at } 10 \mathrm{~Pa}\right) \\
\left.\text { Non-residential buildings: } 200 \mathrm{dm}^{3} / \mathrm{s} \text { per } 500 \mathrm{~m}^{3} \text { (at } 10 \mathrm{~Pa}\right)\end{array}$} \\
\hline $\begin{array}{l}\text { United Kingdom of } \\
\text { Great Britain }\end{array}$ & \multicolumn{2}{|c|}{$\begin{array}{l}\text { New dwellings and new commercial and public buildings } \\
\text { over } 500 \mathrm{~m}^{2}: 10 \mathrm{~m}^{3} / \mathrm{m}^{2} \mathrm{~h} \\
\text { (stated as reasonable limit for the design air permeability in } \\
\text { building regulations } 2000 \mathrm{~L} 1 \mathrm{~A} \text { and L2A) }\end{array}$} \\
\hline
\end{tabular}

\section{Evaluation of the buildings air tightness}

After the renovation works the thermal performance of external building envelope significantly increases. The U-values of walls after thermal insulations is 0.25 $0.30 \mathrm{~W} /(\mathrm{m} 2 \cdot \mathrm{K})$, while for roofs $0.15-0.20 \mathrm{~W} /(\mathrm{m} 2 \cdot \mathrm{K})$. Such thermal bridges as external wall/floor junctions, internal corners and external corners are fully prevented after heat insulation works.

In order to get more objective information of renovation quality, including also changes in ventilation rate, the airtightness tests for kindergarten were done. Figure 1 shows preparation work done for airtightness test. In order to test air leakage rate of building envelope, all ventilation shafts were sealed and all windows and external doors were closed while the internal doors were opened to prevent closed spaces. Preparation works where done in compliance with the requirements of standard EN 13829 [23]. Thermal Performance of Buildings - Determination of Air Permeability of Buildings - Fan Pressurization Method. Brussels: European Committee for Standardization method B. 


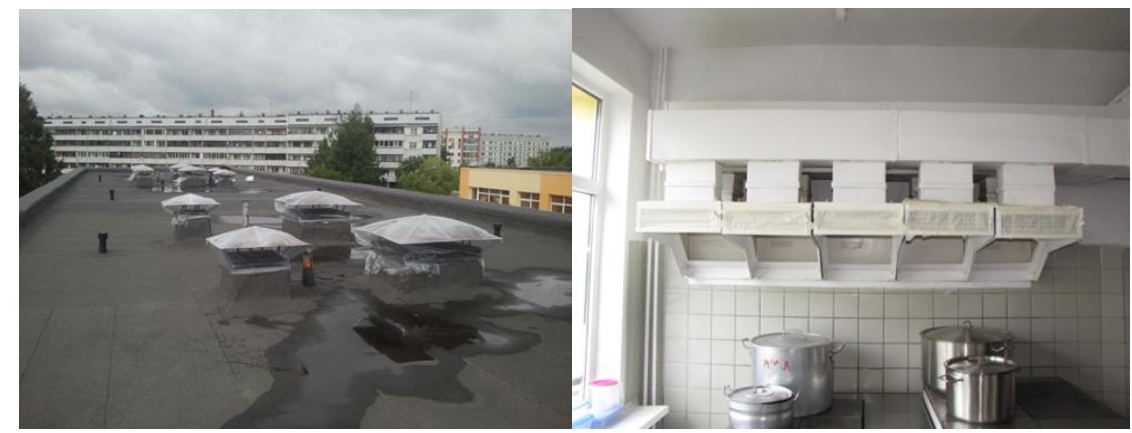

Figure 1. Preparation work for Blower Door test.

Air leakage test was done using two Blower Door installations. Blower Door installations were placed on opposite facades. The total capacity of Blower Door installations was $28000 \mathrm{~m} 3 / \mathrm{h}$. The 3D model of kindergarten and dimensions are shown in Figure 2. Verification was performed in two modes:

- $\quad$ by creating underpressure in range between $40 \mathrm{~Pa}$ and $70 \mathrm{~Pa}$;

- by creating overpressure in range between $25 \mathrm{~Pa}$ and $60 \mathrm{~Pa}$

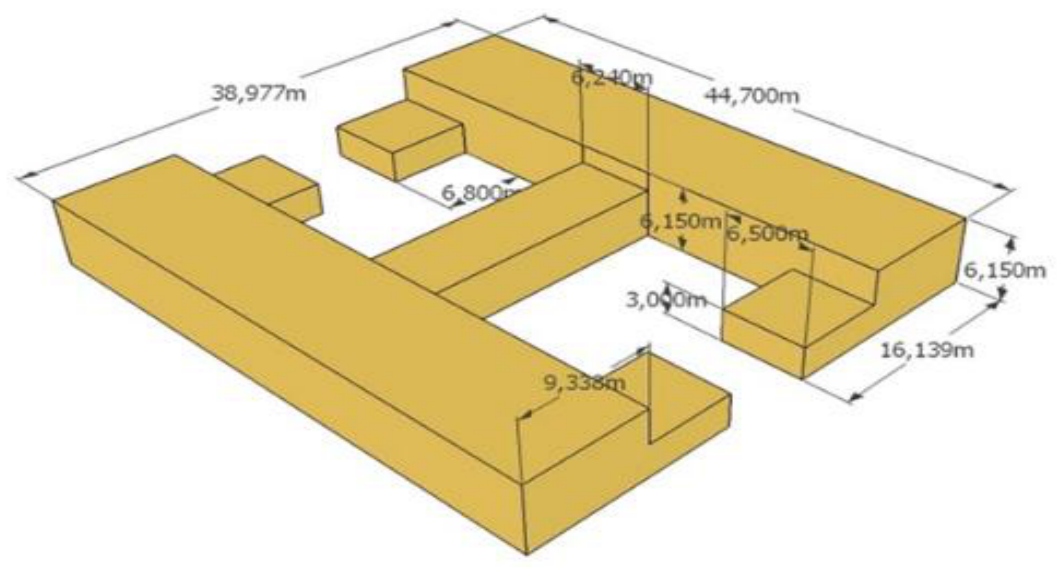

Figure 2. 3D scheme of kindergarten.

Air permeability verification was performed in compliance with standard EN 13829 (methods A and B). Assessment of verification results was performed in compliance with standard LBN 002-01. According to the requirements of LBN $002-01$ air permeability q50 of the buildings envelopes being tested should not exceed $3 \mathrm{~m}^{3} /\left(\mathrm{m}^{2} \cdot \mathrm{h}\right)$, with pressure difference $50 \mathrm{~Pa}$, where:

$$
\mathrm{q} 50=\mathrm{V} 50 / \mathrm{A}_{\mathrm{E}},\left[\mathrm{m}^{3} /\left(\mathrm{m}^{2} \cdot \mathrm{h}\right)\right]
$$

$\mathrm{V} 50$ - the measured air flow that flows through the construction with pressure difference $50 \mathrm{~Pa}\left[\mathrm{~m}^{3} / \mathrm{h}\right]$;

$\mathrm{A}_{\mathrm{E}}$ - area of building's envelope $\left[\mathrm{m}^{2}\right]$.

Additionally, air change rate coefficient $\mathrm{n} 50\left[\mathrm{~h}^{-1}\right]$ with pressure difference $50 \mathrm{~Pa}$ was calculated,

where:

$$
\mathrm{n} 50=\mathrm{V} 50 / \mathrm{V},\left[\mathrm{h}^{-1}\right]
$$

V50 - the measured air flow that flows through the construction with pressure difference $50 \mathrm{~Pa}\left[\mathrm{~m}^{3} / \mathrm{h}\right]$; 
$\mathrm{V}$ - building volume $\left[\mathrm{m}^{3}\right]$.

The results of Blower Door test after renovation are presented in Table 2. In all cases the air leakage rate is in conformity with requirement of LBN 002-01. Air leakage rate according to this code should not exceed $3.0 \mathrm{~m}^{3} /\left(\mathrm{m}^{2} \cdot \mathrm{h}\right)$ for residential buildings, hospitals and kindergartens.

Table 2. Airtightness of buildings envelope in kindergartens after renovation [24].

\begin{tabular}{|c|c|c|c|c|}
\hline Case study & Volume, [m3] & $\begin{array}{c}\text { Area of building } \\
\text { envelope, }[\mathbf{~ m 2}]\end{array}$ & $\begin{array}{c}\text { Air leakage rate } \\
[\mathbf{m 3} / \mathbf{( m 2} \cdot \mathbf{h})] \mathbf{~ q 5 0}\end{array}$ & $\begin{array}{c}\text { Air change rate, } \\
{[\mathbf{h}-\mathbf{1} \text { ]n50 }}\end{array}$ \\
\hline 1 & 4045 & 5358 & 2.89 & 2.19 \\
\hline 2 & 6375 & 4044 & 2.57 & 1.63 \\
\hline 3 & 3895 & 6228 & 2.68 & 1.68 \\
\hline
\end{tabular}

Unfortunately there are no precise data available on air leakage rates of kindergarten buildings before renovation. However measurement of one, partly renovated, kindergarten has shown that the air leakage was $6.5 \mathrm{~m}^{3} /\left(\mathrm{m}^{2} \cdot \mathrm{h}\right)$. In addition to building envelope airtightness evaluation the ventilation systems were also checked in kindergarten "Kamolitis". The ventilation rate under pressure difference $50 \mathrm{~Pa}$ created $4.62 \mathrm{~h}^{-1}$ but under $4 \mathrm{~Pa}-1.29 \mathrm{~h}^{-1}$. In case of complex architecture of some buildings for example as private houses, calculation of area of the envelope and $\mathrm{q} 50\left[\mathrm{~m}^{3} /\left(\mathrm{m}^{2} \cdot \mathrm{h}\right)\right]$ could be challenging, therefore another normative as DIN 4108-7:2011-01 defines the maximum air exchange rate (Tab. 3).

Table 3. Recommended building preparation and recommended maximum air change rates for the airtightness measurement at 50 Pa pressure difference according to DIN 4108-7:2011-01 [25].

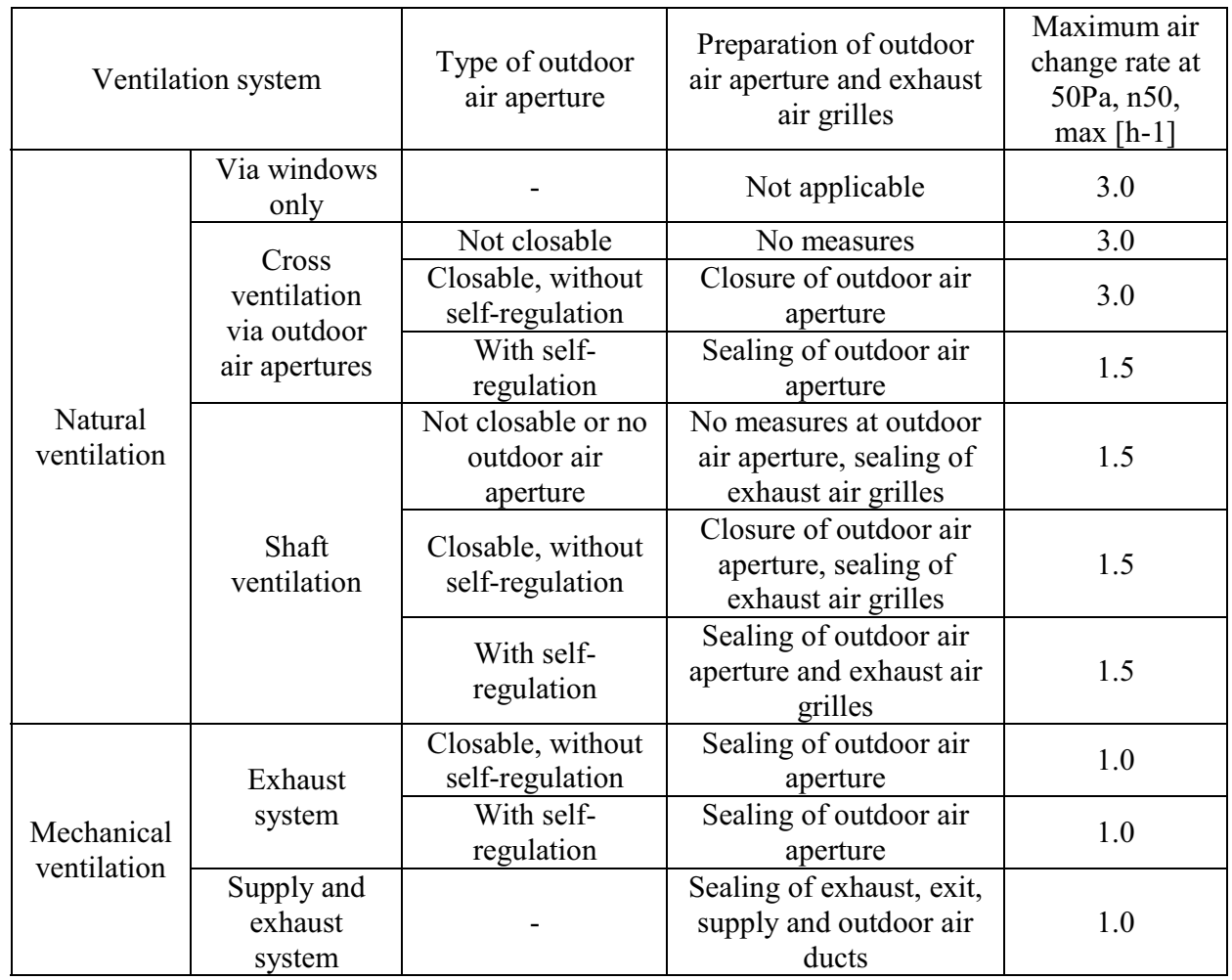


Current study shows that the measured values of the air change rate in the number of private houses differs a lot and depends mostly on the quality of the construction work (Tab. 4).

Table 4. Air change rate in one family houses.

\begin{tabular}{|c|c|c|c|}
\hline Case study & Volume, [m3] & $\begin{array}{c}\text { Air change } \\
\text { rate, [h-1] n50 }\end{array}$ & Description of ventilation system \\
\hline 1 & 310 & 4.78 & MEH \\
\hline 2 & 345 & 0.82 & NAT \\
\hline 3 & 420 & 8.9 & NAT \\
\hline 4 & 467 & 3.6 & NAT \\
\hline 5 & 571 & 3.16 & NAT \\
\hline 6 & 572 & 4.98 & NAT \\
\hline 7 & 610 & 4.2 & NAT \\
\hline 8 & 635 & 6.1 & NAT \\
\hline 9 & 640 & 6.7 & NAT \\
\hline 10 & 725 & 10.75 & NAT \\
\hline 11 & 810 & 8.4 & MEH \\
\hline 12 & 854 & 2.95 & MEH \\
\hline 13 & 1026 & 5.3 & NAT \\
\hline 14 & 1055 & 3.08 & NAT \\
\hline 15 & 1060 & 2.77 & MEH \\
\hline 16 & 1070 & 1.94 & MEH \\
\hline 17 & 1319 & 8.2 & MEH \\
\hline
\end{tabular}

\section{Conclusions}

1. The heat consumption after applying thermal insulation during refurbishment process of buildings can be realistically reduced down to $70 \mathrm{kWh} / \mathrm{m}^{2}$ in typical Latvian climate conditions.

2. The optimal $\mathrm{U}$-values of walls after thermal insulations is $0,25-0,30 \mathrm{~W} /\left(\mathrm{m}^{2} \cdot \mathrm{K}\right)$, while for roofs $0,15-0,20 \mathrm{~W} /\left(\mathrm{m}^{2} \cdot \mathrm{K}\right)$.

3. Due to ventilation systems usually are not renovated, the IAQ measurements in renovated buildings have shown unsatisfactory situation with increased $\mathrm{CO}_{2}$ concentration and high relative humidity.

4. Measurement airtightness of partly renovated kindergarten has shown that the air leakage was $6.5 \mathrm{~m}^{3} /\left(\mathrm{m}^{2} \cdot \mathrm{h}\right)$.

5. The practical measurement of renovated buildings had shown the air leakage rate $\mathrm{q} 50$ of typical Latvian construction after renovation is between 2.5 and $2.9 \mathrm{~m}^{3} /\left(\mathrm{m}^{2} \cdot \mathrm{h}\right)$.

6. On average the share of energy consumption for ventilation needs in renovated building without heat recovery is $50 \%$ of total heat consumption for space heating and ventilation. The IAQ measurements in renovated buildings have shown slightly unsatisfactory situation with increased $\mathrm{CO}_{2}$ concentration higher relative humidity while the energy consumption can almost be reduced to level of energy efficient buildings.

This work partially financially supported by Goverment of Russian Federation (Grant 074-u01). 


\section{References}

1. Information on on: http://www.stb.rwth-aachen.de/projekte/2008/ETHICS/docs/ETX136_Deliverable_WP1_a.pdf

2. V. Pukhkal, M. Tanić, N. Vatin, V. Murgul, Procedia Engineering, 117, 864-869 (2015)

3. V. Murgul, D. Vuksanovic, N. Vatin, V. Pukhkal, Applied Mechanics and Materials, 635-637, 370-376 (2014)

4. V. Pukhkal, N. Vatin, V. Murgul, Applied Mechanics and Materials, 680, 529-533 (2014)

5. V. Murgul, D. Vuksanovic, N. Vatin, V. Pukhkal, Applied Mechanics and Materials, 680, 524-528 (2014)

6. V. Murgul, D. Vuksanovic, V. Pukhkal, N. Vatin, Applied Mechanics and Materials, 633-634, 977-981 (2014)

7. V. Murgul, MATEC Web of Conferences, 53, 01046 (2016)

8. V. Pukhkal, A. Bieliatynskyi, V. Murgul, Journal of Applied Engineering Science, 14(1), 93-101 (2016)

9. A. Milajić, D. Beljaković, N. Davidović, N. Vatin, V. Murgul, Procedia Engineering, 117, 916-923 (2015)

10. A. Gorshkov, V. Murgul, O. Oliynyk, MATEC Web of Conferences, 53, 01045 (2016)

11. V. Pukhkal, N. Vatin, V. Murgul, Applied Mechanics and Materials, 633-634, 1077$1081(2014)$

12. N.I. Vatin. D. V. Nemova, A. S. Kazimirova, and K. N. Gureev, Advanced Materials Research, 953-954, 1537-1544 (2014)

13. N. I. Vatin, D. V. Nemova, D. S. Tarasova, and A. A. Staritcyna, Advanced Materials Research, 953-954, 854-870 (2014)

14. N. Vatin, M. Petrichenko, D. Nemova, A. Staritcyna, and D. Tarasova, Applied Mechanics and Materials, 1, 633-634 (2014)

15. A. Borodinecs, A. Kreslins, E. Dzelzitis, A. Krumins, Ventilation and Energy Conservation in Buildings: Sustainable Built Environment, 361-368 (2007)

16. A. Borodinecs, B. Gaujena, J. Zemitis, A.Kreslins, 12th International Conference on Indoor Air Quality and Climate, 973-978 (2011)

17. A. Borodinecs, Z. Budjko, Indoor air quality in nursery schools in Latvia 9th International Conference and Exhibition - Healthy Buildings (2009)

18. LVS EN 12207:2001 Windows and doors - Air permeability - Classification (2001)

19. Information on: http://www.cmhc-schl.gc.ca/publications/en/rh-pr/tech/98109.htm

20. SP 23-101-2004 Thermal performance design of buildings (Moscow, 2008)

21. E.G. Malyavina, Building Heat Losses (Avok-Press, Moscow, 2007)

22. H. Erhorn, H. Erhorn-Kluttig, F.R. Carrié. Airtightness requirements for highperformance buildings, Conference paper, AIVC, Kyoto, Japan, (2008) Information on http://www.asiepi.eu/wp-5-airtightness/related-papers.html

23. EN 13829 Thermal Performance of Buildings-Determination of Air Permeability of Buildings-Fan Pressurization Method (European Committee for Standardization, Brussels, 2000)

24. A. Borodinecs, A. Rodriguez-Gabriel., O. Tatarchenko, etc. Handbook on Buildings Renovation in Central Baltic Region (Riga Technical University, Riga, 2013)

25. DIN 4108-7:2011-01 Thermal insulation and energy economy in buildings - Part 7: Air tightness of buildings - Requirements, recommendations and examples for planning and performance (2011) 